\title{
Pengembangan Media Pembelajaran Bahasa Inggris untuk Pramuwisata di Desa Wisata Organik Lombok Kulon Bondowoso
}

\author{
Enik Rukiati1 ${ }^{\# 1}$, Nila Susanti ${ }^{* 2}$ \\ \#Jurusan Bahasa, Komunikasi dan Pariwisata, Politeknik Negeri Jember \\ Jl. Mastrip PO BOX 164 Jember \\ ${ }^{1}$ eni rukiati@yahoo.co.id \\ *Jurusan Bahasa, Komunikasi dan Pariwisata, Politeknik Negeri Jember \\ Jl. Mastrip PO BOX 164 Jember \\ ${ }^{2}$ nilasusanti15@gmail. com
}

\begin{abstract}
Pengembangan media pembelajaran bahasa inggris untuk pramuwista di desa wista organik Lombok Kulon, Bondowo merupakan suatu kebutuhan nyata yang harus dialakukan untuik menjawab kebutuhan akan materi pembelajaran bahasa inggris yang mampu meningkatkan kemampuan berkomunikasi (communication competence) bagi anak-anak desa sebagai calon pramuwista di desa wisata Organik lombok kulon. Media pembelajaran dikembangkan dengan melalui beberapa tahapan yaitu 1). Analisa kebutuhan, 2). merumuskan tujuan pembelajaran, 3). menyusun materi 4). menentukan metode 5). merumuskan alat evaluasi. Materi yang disusun diujicobakan kepada para calon pramuwisata melalui kegiatan pelatihan bahasa Inggris dalam wadah English club yang ada di desa Wisata Organik Lobok Kulon. Dari kegiatan ini diperoleh respon dan masukan masukan positif terhadap kegiatan pengabdian yang diadakan.
\end{abstract}

Keywords - media, pengembangan, pramuwisata

\section{Pendahuluan}

Seiring dengan meningkatnya perekonomian masyarakat, kesadaran masyarakat akan pentingnya berwisata dan hidup sehat mengalami peningkatan yang cukup signifikan. Desa Wisata Organik Lombok Kulon, Kecamatan Wonosari menawarkan wisata alam dengan mengunggulkan potensi desa dan kehidupan masyakat pedesaan yang secara apik dikemas dalam bentuk desa wisata. Desa wisata adalah suatu bentuk integrasi antara atraksi, akomodasi dan fasilitas pendukung yang disajikan dalam suatu struktur kehidupan masyarakat yang menyatu dengan tata cara dan tradisi yang berlaku. (Nuryanti, Wiendu, 1993).

Desa wisata organik ini di kembangkan pada tahun 2007 yang diinisiasi oleh pemuda desa setempat dengan membudidayakan daya ikan yang memang ikan merupakan potensi desa yang cukup melimpah. Tahun 2011, budi daya ikan ditingkatkan menjadi budi daya ikan organik dan padi organik. Budi daya ikan organik ini sangat menguntungkan karena perkembangan ikannya lebih cepat namun biaya produksi yang lebih sedikit.
Setelah produk-produk organik yang dihasilkan Lombok Kulon mulai banyak dikenal secara luas, akhirnya pada tahun 2013 desa ini ditetapkan menjadi salah satu desa wisata dengan produk unggulan organik mulai dari beras, sayur mayur, buah-buahan, telur hingga ikan.

Khusus untuk menyambut datangnya wistawan mancanegara, ketua desa menyatakan bahwa anak-anak desa sebagai generasi penerus harus mampu bekomunikasi menggunakan bahasa Inggris karena menguasai bahasa Inggris adalah sangat penting. English is a glogal language (Crystal, 2000). Oleh karena itu, sebagai upaya untuk membuat anak-anak desa wisata organik mempunyai kemampuan berkomunikasi menggunakan bahasa inggris maka diadakanlah kursus bahasa Inggris gratis bagi para remaja setempat yang diwadahi dalam English Club. Kursus bahasa Inggris ini diadakan seminggu sekali dibawah pembinaan seorang tutor sukarelawan dengan latar belakang pendidikan bahasa Inggris yang diperoleh dari lembaga pendidikan non-formal. Buku pegangan yang dipakai berjudul Excellent Step One yang ditebitkan oleh sebuah lembaga pendidikan non-formal. Buku ini berisi materimateri yang terlalu umum bila dipakai untuk pengajaran bahas inggris di desa wisata organik. Hal ini karena tujuan dari pelatihan keterampian bahasa Inggris di desa wisata 
organik ini adalah agar para anak-anak desa mampu berkomunikasi menggunakan bahasa Inggris sebagai seorang pramuwista yang berkewajiban menjelaskan tentang wisata organik kepada wisatawan mancanegara yang datang.

Sejak dibentuknya English Club sampai saat ini kurang menunjukkan hasil yang memuaskan. Ada banyak faktor yang menyebabkan kurang maksimalnya hasil yang diperoleh. Motivasi, persepsi, dukungan serta kurang maksimalnya proses pembelajaran menjadi penyokong kurang berhasilnya pelatihan bahasa Inggris. Media dan metode pembelajaran yang dipakai kurang sesuai dengan yang dibutuhkan oleh anak-anak desa untuk menguasai komunukasi dasar sebagai seorang pramuwista.

Pembelajaran bahasa Inggris bertujuan khusus untuk peningkatan kemampuan berbahasa Inggris sesuai dengan profesi (English for Spesific Purposes) haruslah dirancang dengan serius. Perlu diadakan analisa kebutuhan yang objektif sehingga diperoleh informasi yang akurat sebagai dasar pengembangan program pelatihan, materi pembelajaran serta metode pengajaran yang tepat. Sebagai desa wisata organik yang mengembangkan wisata organik meliputi pertanian padi organik, sayur organik, buah organik, ikan organik serta menawarkan paket-paket wisata seperti tubbing, pembuatan boneka dari pelepah pisang serta go-cycling, maka materi pelatihan bahasa Inggris harus dirancang secara teliti agar peserta pelatihan menguasai komunikasi dasar untuk memperkenalkan dan menjelaskan bidang-bidang ini sehingga tujuan pembelajaran dapat dicapai dengan lebih efektif dan terukur.

\section{TARGET DAN LUARAN}

Target dari program pengabdian kepada masyarakat ini adalah tersusunnya media pembelajaran bahasa Inggris untuk meningkatkan kemampuan berkomunikasi dasar pagi para pramuwista yang ada di Desa Wisata Organik Lombok Kulon, Bondowoso.

Luaran dari kegiatan ini adalah tersusunnya sebuah buku ajar bahasa inggris untuk meningkatkan kemampuan berkomunikasi dasar bagi para pramuwisata khususnya pramuwisata yang ada di Desa Wisata Organik Lombok Kulon Bondowoso. Buku ajar ini disusun berdasarkan kebutuhan bahasa inggris untuk kebutuhan khusus dari para pramuwisata yang ada di Desa Wisata Organik Lombok Kulon. Pengajaran bahasa untuk tujuan khusus (English for Specific Purposes) mengajarkan bahasa secara khusus, unsur-unsur bahasa hanya yang diajarkan adalah bahasa yang diperlukan untuk menunjang kebutuhan penguasaan bahasa tertentu tidak secara keseluruhan (Ricards \& Roger, 2001). Materi -materi yang disusun kemudian diujicobakan kepada peserta kursus dan akan dievaluasi dan direvisi bila ditemukan adanya ketidaksesuaian materi dengan kondisi peserta didik.

Bahan ajar yang akan dikembangkan terdiri dari topik-topik seputar memberikan informasi tentang objek wisata organik, wisata air (tubbing), dan kehidupan masyarakat desa wisata organik.

\section{METODE PELAKSANAAN}

Kegiatan pengabdian kepada masyarakat ini dilakukan melalui tiga tahapan. Ketiga tahapan pelaksanaan kegiatan dirancang dan dibuat agar kegiataan program berjalan dengan efektif dan tepat sasaran. Tahapan kegiatan tersebut meliputi Penyusunan Buku ajar, uji coba dan evaluasi

A.Penyusunan Buku Ajar

Pada tahapan ini, ketua dan anggota pelaksana kegiatan pengabdian merancang pembelajaran bahasa inggris untuk tujuan khusus dengan lebih seksama. Langkah-langkah yang dilakukan antara lain: Pertama, merumuskan tujuan pembelajaran secara spesifik dan terukur. Kedua, menentukan topik ketiga, menyusun materi pembelajaran serta fungsi-fungsi bahasa (language Functions) yang harus dikuasai oleh peserta kursus untuk mencapai tujuan pembelajaran (teaching objectives) yang telah di tentukan. Keempat, menentukan metode pembelajaran yang sesuai dengan karakteristik dan kondisi serta situasi peserta kursus. Kelima, menentukan jenis evaluasi yang dipakai untuk mengukur kemampuan peserta kursus dalam menyerap keterampilan berbahasa yang telah diberikan.

Berdasarkan hasil dari analisa terhadap kebutuhan , situasi dan kondisi yang ada didesa wisata organik Lombok Kulon, Bondowoso maka disusunlah sebuah buku ajar tingkat dasar (elementary) yang dapat digunakan oleh anakanak sebagai calon pramuwisata lokal desa wisata organik Lombok Kulon, Bondowoso. Buku ajar disusun berdasarkan kebutuhan yang diperoleh dari hasil wawancara dengan ketua desa wisata organik Lombok Kulon. Program Pelatihan dan buku ajar dirancang dengan mempertimbangkan tujuan dari program ini adalah untuk meningkatkan kemampuan berkomunikasi peserta didik (communicative competence) maka rancangan pembelajaran yang tepat adalah menggunakan Communicative Language Teaching (CLT).

Communicative Language Teaching (CLT) atau yang dikenal dengan communicative approach adalah sebuah metode pembelajaran yang mengutamakan interaksi antara peserta didik dan pendidik dalam mencapai tujuan pembelajaran yang telah ditentukan. Richard (1992) mendefinisikan CLT sebagai sebuah metode pembelajaran yang menekankan pada tujuan pembelajaran bahasa untuk penguasaan kompetensi komunikasi. Richard \& Roger (2001) merumuskan ciri-ciri pembelajaran CLT sebagai berikut:

1. Pembelajaran menekankan pada berkomunikasi dengan menggunakan bahasa sasaran (target language).

2. Penggunanaa materi-materi otentik dalam proses pembelajaran.

3. Proses pembelajaran memberikan peluang bagi pembelajar untuk fokus tidak hanya pada bahasa saja tetapi juga pada proses 
4. Penggunan pengalaman pribadi dari pembelajar merupakan memberikan kontribusi penting dalam proses pembelajaran dikelas.

5. Aktifitas pembelajaran dilakukan didalam dan diluar kelas.

Berdasar pada beberapa landasan teori dan pendapat dari para pakar bahasa tersebut diatas maka program pelatihan dan penyusunan buku ajar untuk para calon pramuwisata lokal yang ada di desa wisata organik Lombok Kulon disusun. Program disusun melalui beberapa tahanpan. Pertama, merumuskan tujuan pembelajaran. Kedua, menentukan topik dan fungsi-fungsi bahasa ( language functions) . Ketiga, menentukan tata bahasa yang sesuai dengan fungsi-fungsi bahasa. Keempat, mengumpulkan materi otentik dari berbagai sumber. Kelima, menentukan bentuk-bentuk aktifitas pembelajaran dan yang terakhir, menetukan jenis dan bentu penilaian terhadap capaian pembelajaran peserta didik.

\section{B. Uji Coba}

Dalam melaksanakan uji coba (try-out), tim pelaksana kegiatan pengabdian melibatkan tiga orang mahasiswa dari program studi Bahasa Inggris, Jurusan Bahasa, Komunikasi dan Pariwisata, Politeknik Negeri Jember untuk membantu mengelola kelas dan aktif mendampingi peserta kursus bahasa Inggris di English club. Ketiga mahasiswa tersebut adalah mahasiswa aktif yang pada saat penulisan proposal ini mereka berada di semester empat. Mahasiswa tersebut dipilih dengan mempertimbangkan beberapa hal. Pertama, mahasiswa semester empat telah menempuh mata kuliah Instructional Design, Menejemen Pengelolaan Kursus, serta mata kuliahmata kuliah inti program studi. Mata kuliah-mata kuliah tersebut diatas memberikan bekal yang cukup bagi mereka untuk mampu mengelola kelas bahasa dengan baik. Disamping itu, keterampilan bahasa Inggris (Language Skills) mereka juga sudah layak bagi bekal mereka untuk menjadi tutor bahasa Inggris di pendidikan non-formal. Kedua, mahasiswa-mahasiswa tersebut memiliki prestasi akademik yang bagus dengan Indeks Prestasi Akademik (IPK) diatas 3,00. Ketiga, mahasiswa-mahasiswa tersebut berasal dari kabupaten Bondowoso. Pemilihan mahasiswa dari Bondowoso dilakukan dengan dasar pemikiran bahwa para mahasiswa berasal dari daerah yang sama sehingga mereka bisa lebih dekat, bisa berkomunikasi dengan lebih baik dan bisa memberikan motivasi lebih leluasa kepada para pemuda-pemudi peserta kursus di Desa Wisata Organik ini bahwa belajar bahasa inggris sebenarnya mudah dan siapapun dapat menguasai keterampilan berkomunikasi bahasa Inggris dengan lancar dan benar (fluent and accurate) asalkan kita rajin, gigih dan mau kerja keras. Disamping itu, para mahasiswa dapat berkontribusi pada usaha-usaha mengembangkan potensi desa tempat asal mereke sehingga setelah lulus nanti diharapkan mereka dapat menjadi inisitor-inisiataor bagi perkembangan desa mereka dengan berbekal pengalaman yang mereka peroleh dari keterlibatan mereka dalam kegiatan pengabdian kepada masyarakat ini. C.Evaluasi

Evaluasi merupakan tahapan terakhir dalam rangkaian pelaksanaan program pengabdian kepada masyarakat ini. Evaluasi dilakukan oleh ketua pelaksana beserta anggota dengan mengkaji keseluruhan rangakaian kegiatan pelaksanan pengabdian yang telah dilakukan mulai dari persiapan sampai dengan pelaksanaan. Evalusai dilakukan dengan menganalisa rancangan pembelajaran secara keseluruhan yang meliputi analisa tujuan pembelajaran, materi pembelajaran, metode pengajaran, metode evaluasi serta kegiatan-kegiatan pembelajaran yang dipakai dalam memberikan pengalaman belajar berbicara siswa serta mengidentifikasi kendala-kendala yang mungkin timbul dalam penerapan materi yang telah disusun sehingga dapat dirumuskan suatu rujukan yang efektif bagi tutor dalam melaksanankan pengajaran bahasa Inggris non-formal melalui kursus bahasa Inggris dengan lebih efektif, terukur dan berhasil mencapai tujuan pembelajaran yang telah ditentukan.

\section{KELAYAKAN PERGURUAN TINGGI}

Secara fungsional, keberadaan Pusat Penelitian dan Pengabdian kepada Masyarakat (P3M) di Politeknik Negeri Jember tidak dapat diabaikan kedudukan, peran dan fungsinya. Hal ini berkaitan dengan misi sebuah perguruan tinggi yang memiliki tanggung jawab untuk melaksanakan tri dharma perguruan tinggi, yaitu misi teaching, riset dan pengabdian masyarakat. Dalam perspektif tri dharma tinggi, P3M memiliki tugas dan fungsi di bidang penelitian dan pengabdian. Berdasakan legal status, P3M merupakan salah satu lembaga atau unit pelaksana teknis di Politeknik Negeri Jember yang menyelenggarakan kegiatan penelitian dan pengabdian kepada masyarakat.

Pengabdian, di satu sisi merupakan wahana kepedulian civitas akademika Politeknik Negeri Jember terhadap masyarakat. Dalam konteks ini, melalui pengabdian, masyarakat kampus mempraktekkan, menerapkan, mengamalkan potensi ilmu yang dimiliki dan dalam waktu bersamaan dapat dikembangkan untuk membantu masyarakat dalam memecahkan problem sosial. Di sisi lain, lewat pengabdian, insan akademik dapat belajar dari dan tentang living tradition. Banyak informasi, data, dan pelajaran yang berkembang di masyarakat. Potensi ini dapat dimanfaatkan oleh pihak kampus untuk memperkaya bahan ajar, dan sekaligus dapat dijadikan sebagai pijakan melakukan riset. Karena dari sana akan dapat diidentifikasi masalah-masalah dan potensi baru yang dapat diteliti lebih lanjut. Selanjutnya, melalui riset akan ditemukan pengetahuan, informasi, metode baru yang dapat dimanfaatkan bagi bahan ajar dosen, atau untuk memecahkan persoalan kemasyarakatan lebih lanjut. Begitu seterusnya. Dengan kata lain, tanpa pembuktian praktisrealis melalui pengabdian kepada masyarakat [dengan segala bentuk: Kuliah Kerja Nyata, Desa Mitra Kerja, 
Madrasah Binaan, dll] sebuah hasil riset menjadi tidak valid dan proses pendidikan menjadi tidak par exellence, karena tidak mampu mentransformasikan realitas sosial.Dalam setiap kegiatan pengabdian, persoalan yang dihadapi oleh setiap mitra akan berbeda.

Tim pelaksana dalam kegiatan pengabdian ini terdiri dari 2 orang dosen yang memiliki kelayakan untuk mengembangkan media pembelajaran bahasa Inggris. Ketua dan anggota tim pengusul mempunyai latar belakang keahlian dalam bidang pembelajaran Bahasa Inggris dengan spesifikasi pembelajaran skill Bahasa Inggris (speaking dan $E S P$ ) dan pembelajaran komponen bahasa Inggris (writing dan vocabulary). Skill dan komponen tersebut merupakan aspek yang di butuhkan dalam penguasaan bahasa Inggris. Tim peneliti telah berpengalaman melakukan penelitian terkait pembelajaran bahasa Inggris dan melakukan penganbdian masyarakat yang berhubungan dengan Bahasa Inggris. yang akan bertanggung jawab terhadap pelaksanaan seluruh program kegiatan.

\section{HASIL DAN LUARAN YANG DICAPAI}

Hasil dari Kegiatan pengabdian kepada masyarakat yang dilakukan di desa Wisata Lombok Kulon, Bondowoso adalah terbentuknya sebuah buku ajar yang dapat digunakan sebagai materi pembelajaran bahasa Inggris bagi para calon pramuwisata muda yang ada didesa Wisata Organik Lombok Kulon, Bondowoso. Buku ajar ini merupakasn buku ajar tingkat dasar (elementary) yang berisi materimateri pembelajaran bahasa inggris untuk meningkatkan keterampilan berbicara (speaking).

Tujuan pembejaran dari buku ajar yang disusun adalah setelah mempelajari buku ini, peserta didik akan mampu melakukan komunikasi dasar bahasa Inggris yang meliputi menyapa dan memperkenalkan diri, bertanya, mendeskripsikan fungsi, menggambarkan prosedur, mengungkapkan rasa suka dan tidak suka, mengundang, menunjukkan arah (lihat table 4. 1)

Tabel 1 Topik dan Fungsi-fungsi bahasa

\begin{tabular}{|c|c|c|}
\hline No & TOPIC & LANGUAGE FUNCTIONS \\
\hline 1. & On an event & Greeting and Introducing \\
\hline 2. & In the field & Questionning \\
\hline 3. & Cultivating paddy & Decribing function \\
\hline 4. & Breeding Fish & Describing procedure \\
\hline 5. & Go rafting & Inviting \\
\hline 6. & Planting vegetables & $\begin{array}{c}\text { Expressing Likes and } \\
\text { dislike }\end{array}$ \\
\hline 7. & Cycling & $\begin{array}{c}\text { Asking and showing } \\
\text { direction }\end{array}$ \\
\hline
\end{tabular}

Aktifitas pembelajaran yang digunakan dalam pembelajaran dalam buku ajar yang disusunh adalah bermain peran (role-play), pair-work and group work, information gap, interviews, language exchanges and games. Dengan bentuk-bentuk aktifitas pembelajaran ini peserta didik dapat secara maksimal menggunakan bahasa sasaran (bahasa Inggris) yang sedang mereka pelajari.

Materi pembelajaran didapat dari berbagai sumber diantaranya dari media online dan sumber sumber yang lain termasuk pengambilan foto-foto keadaan nyata di desa wisata organik Lombok Kulon untuk dijadikan materi pembelajaran. Pemberian materi otentik ini sangat penting karena lebih sesuai dengan kebutuhan dari peserta didik.

Metode penilaian yang digunakan adalah penilaian proses (on going assessment). Jenis penilaian ini tidak hanya perpaku pada hasil tetapi lebih kepada proses untuk mencapai sebuah hasil. Semua usaha-usaha positif dari peserta didik untuk mencapai tujuan pembelajran duiniai dan dihargai sesuai dengan kemampuan masing-masing individu.

Buku ajar yang disusun berdasarkan hasil analisa kebutuhan serta kondisi dan karakter dari desa wisata Organik Lombok Kulon, Bondowoso. Kondisi dari peserta didik yang merupakan calon pramusita muda yang ada didesa wisata organik Lombok Kulon, Bondowoso ini mayoritas adalah anak-anak usia sekolah dasar (SD) dan sebagian kecil anak-anak usia sekolah menengah pertama (SMP) dan menengah atas (SMA) sehingga materi bergambar dan berwarna sangat menyenangkan bagi mereka.

Metode pembelajan CLT ini sangat sesuai untuk meningkatkan keterampilan berbicara khususnya pagi peserta didik yang ada di desa wisata Organik Lombok Kulon ini. Anak-anak calon pramuwisata merasa sangat gembira karena mendapatkan mereka belajar melalui bervariasi kegiatan. Kegiatan yang paling mereka suakai adalah bermain peeran dan outdoor class activity. Melalui kegiatan ini anak-anak dapat secara lebih leluasa menggunakan bahasa Inggris dalam menyelesaiakan kegiatan pembelajaran yang ditugaskan kepada mereka.

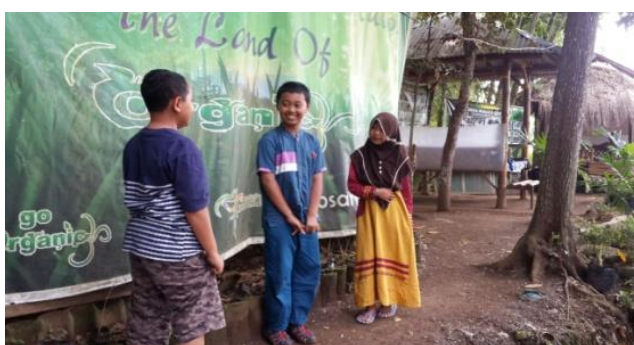

Gambar 1. Kegiatan pembelajaran berupa bermain peran (role-play).

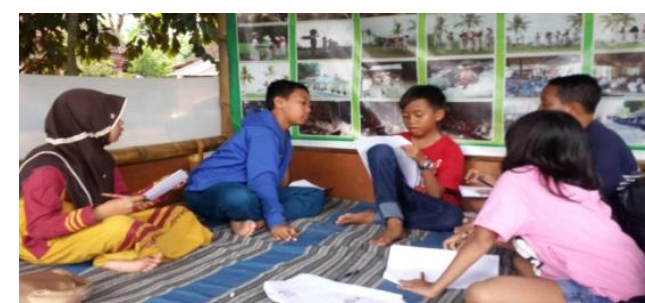

Gambar 2 .Kegiatan pembelajaran dalam diskusi kelompok kecil (small group discussion)

Kegiatan pembelajaran bahasa Inggris didesa ini mengalami sedikit kendaa diantaranya. Pertama, anak-anak yang disiapkan untuk menjadi pramuwisata berjumlah 100 
orang anak akan tetapi sebagian besar keluar dari desa ini dan menetap di pesantren untuk melanjutkan jenjang pendidikan formal mereka sehingga yang tersisa di desa itu ada sekitar 50 anak. Pada saat ini anak-anak yang ada di desa wisata Organik Lombok Kulon mayoritas adalah anakanak usia sekolah dasar dan sabagian kecil anak-anak usia sekolah menengah pertama dan atas. Kedua, keterbatasan sarana dan prasarana serta buku-buku penunjang yang sangat diperlukan anak-anak untuk menambah wacana dan membuka wawasan. Ketiga, media pembelajaran masih terbatas pada penggunaan media cetak (printed material) belum didukung oleh jaringan internet dan materi-materi audio-visual.

\section{KESIMPULAN DAN SARAN}

Pengembangan media pembelajaran bahasa inggris untuk calon pramuwisata yang ada di Desa Lombok Kulon, Wonosari, Bondowo sangat bermanfaat bagi para peserta pelatihan. Hal ini dikarenakan buku ajar yang disusun telah di rancang berdasarkan kebutuhan nyata dari para pramuwisata. Disamping itu, topik dan fungsi-fungsi bahasa disesuaikan dengan objek-objek wisata yang ada di desa Wisata Organik Lombok Kulon sehingga para pramuwisata dapat dengan mudah untuk menyerap materi dan mempraktekkan langsung di objek-objek wisata yang ada di desa Wisata Organik Lombok Kulon.

Bahan ajar yang telah dikembangkan dengan tujuan untuk meningkatkan keterampilan berbicara para pramuwisata yang ada di desa Wisata Organik Lombok Kulon ini memberikan manfaat dengan lebih baik dan terus bermanfaat apa bila didukung oleh yang pertama dan utama adalah adanya motivasi yang tinggi dari para calon pramuwista yang ada didesa ini untuk menggunakan buku ajar yang telah disusun sebagai materi tambahan untuk menambah wacana dalam belajar. Yang kedua, adanya kemauan untuk terus belajar dan berlatih menggunakan bahasa inggris dalam kemunikasi sehari-hari. Dengan demikian, berkomunikasi menggunakan bahasa inggris akan menjadi kebiasaan (habit) bagi mereka. Yang ketiga, adanya media pembelajaran yang tepat dan sesuai dengan karakter para pramuwista. Media pembelajaran yang bervariasi akan menumbuhkan keinginan dan gairah untuk belajar. Disamping itu, media pembelajaran yang bervariasi mampu menigkatkan keterlibatan serta peran aktif dari peserta pelatihan dalam melakukan kegiatan-kegiatan pembelajaran. Keempat, ketersediaan sarana dan prasarana untuk memperlancar dan mempermudah para calon pramuwisata yang ada di Desa Wisata Organik ini untuk terus belajar bahasa inggris sangat diperlukan.

Buku ajar yang disusun masih terbatas untuk penguasaan kemmapuan berkomunikasi tingkat dasar (elementary) sehingga kegiatan ini perlu untuk dilanjutkan engan penyususnan materi untuk tingkat pre-intermediate dan intermediate.

\section{UCAPAN TERIMA KASIH}

Tim mengucapkan terima kasih kepada Politeknik Negeri Jember yang telah mendanai kegiatan pengabdian kepada masyarakat ini dengan menggunakan dana BOPTN melalui Pusat Penelitian dan Pengabdian (P3M) Politeknik Negeri Jember.

\section{DAFTAR PUSTAKA}

[1] Crystal, D. 2003. English as a Global Language Second Edition. Cambridge. Cambridge University Press.

[2] Nuryanti, Wiendu. 1993. Concept, Perspective, and Challanges. Gajah Mada University Press. Yogyakarta.

[3] Richards, J.C., Platt,J., \& Platt,H. (1992). Dictionary of Language Teaching and applied linguistics. UK. Longman Publishing Group.

[4] Ricahrds, J.C, \& Rogers, T.s. (2001). Approaches and Methods in Language Teaching. Cambridge. Cambridge University Press. 